Vol. 2 No. 1- April 2021

\title{
When Will Human Capital in Indonesia be Equal? A Convergence Analysis
}

\author{
Nayaka Artha Wicesa ${ }^{1 *}$, Axellina Muara Setyanti \\ Department of Economics, Faculty of Economics and Business \\ University of Brawijaya, Malang, Indonesia..$^{1,2}$ \\ Email: ${ }^{1}$ nayakaarthawicesa@ub.ac.id, 2axellinamuara@ub.ac.id. \\ ${ }^{*}$ Corresponding author
}

\begin{abstract}
One of the problems faced by developing countries is income inequality, which is caused by weak and uneven human capital between regions. This research aims to determine the convergence of human capital in absolute and conditional with the explanatory variable of government expenditure in education. The method used is panel data regression with generalized least square and robust standard error. The results showed that provinces in Indonesia experienced human capital convergence in absolute, where inequality of human capital among provinces tended to decline over time and towards equity. The results also showed that provinces in Indonesia experienced human capital convergence in conditional, where government expenditure in education was able to accelerate the convergence process, but not significantly. This study also found that the time needed to equalize human capital in Indonesia is 164 years.
\end{abstract}

Keywords: human capital, government expenditures in education, convergence analysis

\begin{tabular}{|c|c|c|}
\hline $\begin{array}{l}\text { Received: November 14, } 2020 \\
\text { Received in revised form: March 16, } 2021 \\
\text { Accepted: March 28, } 2021\end{array}$ & $\begin{array}{l}\text { JISDeP - The Journal of Indonesia } \\
\text { Sustainable Development Planning } \\
\text { Published by Centre for Planners' } \\
\text { Development, Education, and Training } \\
\text { (Pusbindiklatren), } \\
\text { Ministry of National Development } \\
\text { Planning/ National Development } \\
\text { Planning Agency (Bappenas), Republic } \\
\text { of Indonesia }\end{array}$ & $\begin{array}{l}\text { Address: Jalan } \begin{array}{c}\text { Proklamasi } \\
\text { Central Jakarta, Indonesia }\end{array} \quad 10320 \\
\text { Phone:+622131928280/31928285 } \\
\text { Fax:+622131928281 } \\
\text { E-mail: } \\
\text { journal.pusbindiklatren@bappenas.go.id } \\
\text { Supported by Indonesian Development Planners } \\
\text { Association (PPPI) }\end{array}$ \\
\hline
\end{tabular}




\section{Introduction}

There is so much empirical evidence that finds the important role of human capital in the economic development of a country. Benhabib and Spiegel (1994) found that the level of the human capital of a country positively affects the level of productivity. Human resources are an important factor that a country should develop because the existence of quality human resources will increase productivity which has implications for economic development. The reciprocal relationship between economic growth and human capital growth is an important key to sustainable economic growth (Gillies, 2017; Islam et al., 2016; Mincer, 1995).

Human capital is a term often used by economists to refer to education, health, and other human capacities which, if improved, can increase productivity (Todaro \& Smith, 2011). Becker (2002) defines human capital as the knowledge, information, ideas, skills, and health of an individual. Meanwhile, according to Acemoglu \& Autor (2005), human capital is defined as things related to workers' knowledge or characteristics, either innate or acquired, which will later contribute to productivity.

To date, there is no generally accepted agreement regarding what indicators are used to measure human capital, so any research that uses human capital will vary widely in how it is measured. Throughout existing scientific writings, the majority of definitions of human capital tend to be proxied from education.

The formation of human capital can be sourced from education (Colantonio et al., 2010). One problem with the measurement of human capital is that schools are often perceived as the only source of human capital and skills (Bloom et al., 2004). However, Hanushek (2013) explained that with regard to human resources, the measurement of education quality is not limited to school attainment but also cognitive skills. Without improving the quality of schools, developing countries will find it challenging to improve their long-term economic performance.

Indonesia has reformed the relationship between the central and regional governments by decentralizing most government functions to regional governments since 1999. As a consequence, the education sector has become one of the basic service sectors that have undergone fundamental changes, both in terms of the bureaucracy of the authority to provide education and the aspect of funding. (Subijanto, 2010). Along with decentralization, the quality of human resources in a region becomes the responsibility of the region itself. There are a number of budgets that flow massively from the central government to local governments. As a result, the subjects and objects of development are closer to the local governments who have discretionary authority to manage the budget. Therefore, regional development can be maximally optimized for the benefit of many people in the region. This is because the purpose of decentralization itself is to make decisions that are closer to the community so as to produce programs and services that better meet the needs of local communities (Channa \& Faguet, 2016; Work, 2002).

Public spending, including local government, will achieve much better output if distributed and allocated to specific components, such as investment spending. This is because government spending in a broad sense does not actually generate economic growth Purnastuti \& Suprayitno, (2016). The greater the investment made by the government, the higher the growth that will be achieved. In its development, human capital investment is an important expenditure because it aims to improve the quality of human resources itself. Given the fact that human resources are the main production factor in generating output at the micro and macro levels, this investment is worth making, although the benefits are not short-term.

However, it cannot be denied that development in Indonesia is still Java-centric. In 2019, Java Island contributed 59\% to Indonesia's Gross Regional Domestic Product, equivalent to IDR 9487 trillion. The second-largest contributor is Sumatra Island (21,3\%), with a GDP of 3427 Trillion Rupiah. While the rest is distributed on Kalimantan Island (8,1\%), Sulawesi Island (6,3\%), Bali and Nusa Tenggara Island (3,1\%), and Maluku and Papua (2,2\%) (BPS, 2019a). Also, in 2019, human development achievements at the provincial level in Indonesia varied considerably. HDI at the provincial level ranges from 60,84 (Papua) to 80,76 (DKI Jakarta) (BPS, 2020). Indonesia's development is expected to be more than development centered on Java or Sumatra but evenly distributed throughout the region. A regional level analysis is important to study the conditions of inequality in human resource development related to decentralization, whether it is increasingly converging or divergent. The regional/provincial approach is considered to be better at capturing differences in human resources quality than the national approach, especially when convergence analysis is employed (Gennaioli et al., 2013; Zhang et al., 2019).

This study uses convergence analysis to see the development direction of the human capital gap at the provincial level in Indonesia. Particular attention is given to local government spending that supports the human capital formation, the education budget. Through the measurement of convergence, it can be 
seen that there is a tendency to narrow economic disparities between regions within a certain period (Sala-i-Martin, 1996). Satriotomo (2003) also explains that in convergence theory, the level of prosperity experienced by developed regions and developing regions will one day meet at one point. Economics also states that there will be a catching-up effect when developing countries catch up with developed countries. This catching-up effect process is also known as the convergence process. So, the objectives of this study are 1) to find out whether the provinces in Indonesia experience absolute convergence of human capital; 2) to learn whether the provinces in Indonesia experience convergence of human capital conditionally with explanatory variable, government spending on education.

\section{Literature Review}

From a normative point of view, Oates (2005) states that the diversity of preferences between regions is the most fundamental reason that the government structure shifts towards decentralization. This view was later called the "Decentralization Theorem." Previously, Oates (1993) also states that there must be strong reasons to formulate policies for the provision of infrastructure and human resources. However, government policies are sensitive to regional conditions, so to be more effective in promoting economic development, the policies should be locally determined to match with the geographical needs (Busemeyer, 2008; Esteller \& Solé, 2005).

One type of decentralization that is closely related to education is fiscal decentralization. When decentralization is followed by the term fiscal, it refers to "budget practices" and "reallocation of resources" to local governments to improve quality and effectiveness in carrying out government tasks while expanding the authority and capacity of government at the local level (Ocheni \& Agba, 2018; Work, 2002). So, in the context of education, fiscal decentralization is an effort to give wider authority to regions to make breakthroughs in education implementation (Musanna \& Bahri, 2011). Burki stated in Subijanto (2010) that conceptually there are two types of decentralization in terms of education. First is the decentralization of authority in the education sector in terms of education policies and aspects of funding from the central government to local governments (provincial, district, or city). Second is the decentralization of education with a focus on granting greater authority at the school level. The first concept of education decentralization is mainly related to regional autonomy and decentralization of governance from the capital to provinces. In contrast, the concept of decentralization of education which focuses on granting greater authority at the school level is carried out with the motivation to improve the quality of education outcomes.

In Indonesia, human resource convergence in an earlier study conducted by Anwar (2018) is determined by several factors such as socio-economic conditions and access to regional infrastructure. In the first period (2004-2010), human resource convergence in Indonesia was determined by economic growth, poverty, illiteracy, access to clean water, sanitation, the number of health centers and universities. However, in the second period (2010-2016), the convergence was influenced by economic growth, poverty, and access to sanitation. In most studies on human capital, it is shown that education, wages, health, experience, social development are perfectly associated with human capital development (Islam et al., 2016).

According to human capital theory, education plays a vital role in driving economic growth. The better the investment that individuals make in education, the better they will be and the economic outcomes they will get (Gillies, 2017). The latest study by Nurarifin and Ridena (2020) shows that human capital positively affects Indonesia's per capita income, but the magnitude is relatively small. Thus, it is very important to study human capital in Indonesia. Recently, the definition of human capital has broadened to include not only knowledge or skills but also competencies, traits, and attitudes such as reliability, honesty, independence, and individual responsibility (Becker b, 2002).

\section{Methodology}

This study uses a quantitative approach using secondary data taken from the Ministry of Finance's General Directorate of Fiscal Balance (Direktorat Jenderal Perimbangan Keuangan - DJPK) and the Central Statistics Agency. The population in this study is Indonesia's territory, with a sample of 33 provinces during the period 2005-2019. The variables used in this study consisted of the independent variable, the human capital index and government spending in education, and the dependent variable, the growth of the human capital index. 


\section{Operational Definition of Variables}

The operational definitions of the research variables are as follows:

1. Government Expenditure on Education is defined as the amount of government spending by function on education (Lucas \& Shobayo, 2017).

2. Human Capital Index growth is defined as the percentage change in the index in year t and year $\mathrm{t}-1$.

3. The Human Capital Index is defined as a measure that describes the knowledge, information, ideas, and expertise of an individual, all of which can be obtained through formal education. Thus, several previous researchers proxied human capital using school enrollment rates (Altiner \& Toktas, 2017; Barro, 2001; Hanushek, 2013; Mankiw et al., 1992; Murthy, 1997). The Human Capital Index in this study was formed using the method developed by the World Economic Forum (2017), which the authors further modify as follows.

\section{Human Capital Composite Index}

The formulation of the human capital composite index was adopted from the formulation of the human development index used by UNDP (2016). The formula is as follows :

$$
H C I=w_{1} * D I_{1}+w_{2} * D I_{2}+\ldots+w_{n} * D I_{n}
$$

$\mathrm{HCl}$ is the human capital index, $\mathrm{w}$ is the weight of dimension index, $\mathrm{DI}$ is dimension index, and $\mathrm{n}$ is the number of dimensions. Dimension index is an index that shows the value of each dimension based on a predetermined weight. Dimensions are components of the composite index.

Table 1. Human Capital Index Structure

\begin{tabular}{|c|c|c|}
\hline \multirow{5}{*}{$\begin{array}{l}\text { Human } \\
\text { Capital Index }\end{array}$} & $\begin{array}{l}\text { Dimensions } \\
\text { (weight) }\end{array}$ & The Operational Definition of the Dimensions \\
\hline & $\begin{array}{c}\text { Elementary School Education } \\
\text { Participation Rate } \\
(25 \%)\end{array}$ & $\begin{array}{l}\text { The percentage of population members between } 7 \text { and } 12 \text { years old } \\
\text { who are currently attending elementary school }\end{array}$ \\
\hline & $\begin{array}{l}\text { Junior High School Education } \\
\text { Participation Rate } \\
(25 \%)\end{array}$ & $\begin{array}{l}\text { The percentage of population members between } 13 \text { and } 15 \text { years old } \\
\text { who are currently attending junior high school }\end{array}$ \\
\hline & $\begin{array}{l}\text { Senior and Vocational Junior High } \\
\text { School Education Participation Rate } \\
\text { (25\%) }\end{array}$ & $\begin{array}{l}\text { The percentage of population members between } 16 \text { and } 18 \text { years old } \\
\text { who are currently attending senior and vocational high school }\end{array}$ \\
\hline & $\begin{array}{l}\text { Higher Education Participation Rate } \\
\qquad(25 \%)\end{array}$ & $\begin{array}{l}\text { The percentage of population members between } 19 \text { and } 24 \text { years old } \\
\text { who are currently attending higher education }\end{array}$ \\
\hline
\end{tabular}

Source: World Economic Forum (2017), modified

\section{Dimensional Index Calculation Method}

The formula for calculating the dimensional index is as follows:

$$
\text { Dimensional Index }=\frac{(\text { Actual Value }- \text { Minimum Value })}{(\text { Maximum Value }- \text { Minimum Value })}
$$

The minimum value is the lowest value of all data observed during the observation period. The maximum value is the highest value of all observed data during the observation period. As a result, the index will have the highest value of 1 and the lowest value of 0 . The minimum and maximum values will differ from year to year. 


\section{Panel Data Analysis: Absolute and Conditional Convergence}

There are several methods used in estimating the panel data regression model, namely Common Effect, Fixed Effect, and Random Effect. Common Effect is a model that cannot distinguish the variance between cross places and points in time because it has a fixed intercept and does not vary randomly. Fixed Effect is a model that assumes that the intercept is different for each subject while the slope remains the same between subjects. Random Effect is a model in which the residual variable is thought to have a relationship between time and between subjects. To select the best model from the three models, the Chow, Hausman, and Lagrange multiplier tests were carried out. The model to be estimated in this study adopts the model developed by Barro \& Sala-i-Martin (1991) as follows.

Model 1: Absolute Convergence

$$
\Delta H C I_{i t}=\beta_{0}+\beta_{1} L n_{-} H C I_{i t-1}+\mu_{i t}
$$

where:

$\begin{array}{ll}\Delta \mathrm{HCl} & : \text { Human Capital Index Growth (\%) } \\ \beta_{0} & : \text { Constant } \\ \beta_{1} & : \text { Convergence Coefficient } \\ \text { Ln_HCl } \mathrm{H}_{-1} & : \text { Natural Logarithm of Human Capital Index Early Years of Analysis } \\ \mu & : \text { Error Term } \\ \mathrm{i} & : \text { Province } \\ \mathrm{t} & : \text { Year }\end{array}$

Model 2: Conditional Convergence

$$
\Delta H C I_{i t}=\theta_{0}+\theta_{1} L n_{-} H C I_{i t-1}+\theta_{2} L n_{-} G E E_{i t}+\varepsilon_{i t}
$$

Dimana:

$\begin{array}{ll}\Delta \mathrm{HCl} & : \text { Human Capital Index Growth (\%) } \\ \theta_{0} & : \text { Constant } \\ \theta_{1} & : \text { Convergence Coefficient } \\ \theta_{2} & : \text { Coefficient of Variable Affecting Conditional Convergence } \\ \text { Ln_HCl } \mathrm{t}_{-1} & : \text { Natural Logarithm of Human Capital Index Early Years of Analysis } \\ \text { Ln_GEE } & : \text { Natural Logarithm of Government Expenditure in Education } \\ \varepsilon & : \text { Error Term } \\ \mathrm{i} & : \text { Province } \\ \mathrm{t} & : \text { Year }\end{array}$

Convergence Coefficient $\beta_{1}$ dan $\theta_{1}$ are units that can be used to calculate the speed of convergence. If $\beta_{1}$, $\theta_{1}<0$, convergence occurs, and if $\beta_{1}, \theta_{1}>0$, divergence occurs. Perfect convergence is reached if $\beta_{1}, \theta_{1}=$ -1 and perfect divergence is reached if $\beta_{1}, \theta_{1}=1$. The speed of convergence $(\lambda)$ of a region can be calculated using the following formulas:

$$
\lambda=-\frac{\left[\ln \left(\beta_{1}+1\right)\right]}{T} \quad \lambda=-\frac{\left[\ln \left(\theta_{1}+1\right)\right]}{T}
$$


$\mathrm{T}$ is the number of observation years. By using the value of each coefficient of convergence, the half-life of convergence (h), i.e., the time required to close a half of the inequality, can be calculated using the following formula:

$$
h=\frac{\ln (2)}{\lambda}
$$

\section{Results and Discussion}

Community participation in education is the initial process of forming human capital. The formation of human capital is important for a country because the knowledge and skills in humans will directly increase their productivity and indirectly increase the ability to develop and adopt new technologies (de la Fuente, 2011).



Figure 1. School Enrollment Rates in Indonesia, 2000 - 2019

Source: BPS, 2020 (compiled by the author)

The level of community participation in education and the formation of human capital is quite widely measured by the School Participation Rate (Gillies, 2017; Zhang et al., 2019). One indicator that can be used to observe the success of the Education Development Program, the certainty of getting an education or equal distribution of education services at the national, provincial, and municipal levels, is through the Gross Participation Rate and Pure Participation Rate at various levels of education (Ministry of Education, 2019). The School Enrollment Rate in Indonesia can be seen in Figure 1.

In general, it can be seen that the School Participation Rate at each level of education continues to increase from year to year. This means that the number of people who receive education according to school-age ranges has increased. However, between education levels, there is still quite a gap. On a national average during the period 2000-2019, the School Participation Rate for Elementary School was 97,76\%, Junior High School was 87,53\%, then decreased at the Senior High School and University levels with a School Participation Rate of $59,77 \%$ and $16 \%$, respectively. School Participation Rate in higher education is still very low. Only 1 in 6 of the population aged 19-24 years is able to access education at higher education. A greater number of participation rates at one level of education indicates the quality of government services to the right of the community to gain access to education. The amount of the participation rate also shows that the community has easy access to leap into another level (Wahyudin \& Caturwati, 2019). Thus, the low percentage of higher education indicates difficulties for the community in accessing it. Provinces with the highest participation rates were DI Yogyakarta, Aceh, and Maluku, while the lowest was Papua, West Sulawesi, and the Bangka Belitung Islands. Compared to several ASEAN countries, Indonesia's Higher Education Gross Enrollment Rate is still behind compared to Singapore's $78 \%$ and Malaysia's 38\%. Higher education is the key to a country's progress in achieving prosperity through adaptation and innovation (Ministry of Finance, 2018). The backward development of higher education is caused by the priority of new education development from the 9-year compulsory education to the 12-year compulsory education. As the results, the Gross Enrollment Rate and Net Enrollment Rate for Basic Education reach more than 95\%, while Higher Education is still far below it. 




Figure 2. Number of Workers in Indonesia Based on the Highest Enrolled Education, 2000 - 2020 Source: BPS, 2021 (compiled by author)

The condition of school participation in Indonesia will impact the quality of the workforce. Figure 2 shows that elementary school graduates still dominated the workforce in Indonesia, followed by junior high school, high school, vocational high school, and university graduates, while the number of workers who never went to school was the least and decreasing. This shows that the compulsory education program has been implemented properly by the government. Then, there is a trend towards improving the quality of the workforce in Indonesia, which is shown by the decreasing number of workers with primary education. The workforce with junior high school education also shows slower growth. On the other hand, the workforce with high school education shows a higher growth. Thus, the number of workers with junior and senior high school education is almost the same. It seems that this pattern will experience a shift in the next few years where the number of workers with high school education will outnumber those with junior high school education. Workforce with SMK education shows an upward trend with high growth, and tertiary education workers also show similar trends. However, looking at the distribution, the number of workers with tertiary education is still low compared to other levels of education.

Based on empirical studies in Indonesia, the implementation of decentralization has positive and negative impacts on the delivery of public services such as education (Purwanto \& Pramusinto, 2018). Azzizah (2015) shows a substantial gap between eastern and western Indonesia. The increase in education expenditure in developed regions has an impact on increasing efficiency and accelerating economic growth. Unfortunately, this does not have a significant impact on increasing human capital and reducing poverty (Saraswati, 2012). The impact of decentralization on human capital in the regions can be observed from the following estimation results: 
Table 2. Estimation Results of Absolute Convergence

\begin{tabular}{|c|c|c|c|c|c|c|}
\hline \multicolumn{7}{|c|}{ Dependent Variable: $\Delta \mathrm{HCl}$} \\
\hline \multirow{2}{*}{$\begin{array}{l}\text { Independent } \\
\text { Variable }\end{array}$} & \multicolumn{2}{|c|}{ Common Effect Model } & \multicolumn{2}{|c|}{ Fixed Effect Model } & \multicolumn{2}{|c|}{ Random Effect Model } \\
\hline & Coeff & Prob & Coeff & Prob & Coeff & Prob \\
\hline $\mathbf{C}$ & $0,3924 * * *$ & 0,000 & $0,4636 * * *$ & 0,000 & $0,3924 * * *$ & 0,000 \\
\hline Ln_HCl $I_{t-1}$ & $-0,0870 * * *$ & 0,000 & $-0,1046 * * *$ & 0,000 & $-0,0870 * * *$ & 0,000 \\
\hline R-Squared & \multicolumn{2}{|c|}{0,1039} & \multicolumn{2}{|c|}{0,0809} & \multicolumn{2}{|c|}{0,0809} \\
\hline Prob (F-Stat) & \multicolumn{2}{|c|}{0,0000} & \multicolumn{2}{|c|}{0,0000} & \multicolumn{2}{|c|}{0,0000} \\
\hline Convergence / Divergence & \multicolumn{2}{|c|}{ Convergence Occurs } & \multicolumn{2}{|c|}{ Convergence Occurs } & \multicolumn{2}{|c|}{ Convergence Occurs } \\
\hline Speed of Convergence $(\lambda)$ & \multicolumn{2}{|c|}{$0,65 \%$} & \multicolumn{2}{|c|}{$0,79 \%$} & \multicolumn{2}{|c|}{$0,65 \%$} \\
\hline The Half-Life of Convergence & \multicolumn{2}{|c|}{107 Years } & \multicolumn{2}{|c|}{88 Years } & \multicolumn{2}{|c|}{107 Years } \\
\hline The Whole Life of Convergence & \multicolumn{2}{|c|}{214 Years } & \multicolumn{2}{|c|}{176 Years } & \multicolumn{2}{|c|}{214 Years } \\
\hline note : significance level $* * * 1 \%, *$ & & & & & & \\
\hline
\end{tabular}

The Random Effect Model produced the best model. According to Gujarati and Porter (2015), if the method used is the Random Effect Model, it can ignore the problem of classical assumption violations because the REM method uses Generalized Least Square (GLS). Based on Table 2, the influence of the independent variable on the dependent variable can be seen in the individual significance test. The estimation results show that the Human Capital Index variable at the beginning of the analysis has a significant negative effect on the growth of the Human Capital Index at $\alpha=1 \%$. This means that provinces in Indonesia are experiencing absolute convergence of human capital at a rate of 0,65\% per year. The Half-Life of Convergence and The Whole Life of Convergence are 107 years and 214 years, respectively. The coefficient of determination of 0,0809 means that the variation in the growth of the Human Capital Index can be explained by the model at $8,09 \%$, and the remaining $91,91 \%$ is explained by other variables outside the model.

From the estimation results above, this study finds that human capital represented by the components of the School Participation Rate has converged, or in other words, even distribution is evident across regions. The estimation also found that to equalize human capital, especially education, takes a very long time, at 107 years, to close half of the initial gap and at 214 years, to close the entire gap. The zoning system and teacher rotation can be mentioned as government efforts to equalize the quality of education in Indonesia. Equity in the field of education is not only limited to the number of people who can attend school, but the quality of output resulting from the education process. The average length of schooling in Indonesia in 2019 is 8,75 years (BPS, 2019b). Even though it has met the Ministry of Education and Culture's Strategic Plan with the average target length of schooling at 8,7 years, this achievement is still equivalent to junior high school education.

Concerning the objectives of decentralization in education, two prerequisites must receive attention: delegation and facilitation (Jalil, 1999). Decentralization is not possible without the delegation of authority from the central government to local governments. The delegation has been implemented about two decades after decentralization, but facilitation is still required. Although the authority to handle the education sector has been partially delegated, the central government needs to provide support to the regions to be able to implement decentralization responsibly. However, with the limitations each region has, financing and the capacity of human resources to implement this policy tend to cause complications and lead to inefficiencies in education management (Musanna \& Bahri, 2011). In the second objective of the research, we want to know the state of conditional convergence of human capital if government spending on education is used as an explanatory variable. 
Table 3. Estimation Results of Conditional Convergence

\begin{tabular}{|c|c|c|c|c|c|c|}
\hline \multicolumn{7}{|c|}{ Dependent Variable: $\Delta \mathrm{HCl}$} \\
\hline \multirow{2}{*}{$\begin{array}{l}\text { Independent } \\
\text { Variable }\end{array}$} & \multicolumn{2}{|c|}{ Common Effect Model } & \multicolumn{2}{|c|}{$\begin{array}{l}\text { Fixed Effect Model: } \\
\text { Robust Standard Error }\end{array}$} & \multicolumn{2}{|c|}{ Random Effect Model } \\
\hline & Coeff & Prob & Coeff & Prob & Coeff & Prob \\
\hline C & $0,4861^{* * *}$ & 0,000 & $0,5183^{* * *}$ & 0,000 & $0,4861^{* * *}$ & 0,000 \\
\hline Ln_HCl $I_{t-1}$ & $-0,0816 * * *$ & 0,000 & $-0,1040 * * *$ & 0,004 & $-0,0816 * * *$ & 0,000 \\
\hline Ln_GEE & $-0,0042$ & 0,108 & $-0,0020$ & 0,463 & $-0,0042$ & 0,107 \\
\hline R-Squared & \multicolumn{2}{|c|}{0,1127} & \multicolumn{2}{|c|}{0,0848} & \multicolumn{2}{|c|}{0,0835} \\
\hline Prob (F-Stat) & \multicolumn{2}{|c|}{0,0000} & \multicolumn{2}{|c|}{0,0000} & \multicolumn{2}{|c|}{0,0000} \\
\hline Convergence / Divergence & \multicolumn{2}{|c|}{ Convergence Occurs } & \multicolumn{2}{|c|}{ Convergence Occurs } & \multicolumn{2}{|c|}{ Convergence Occurs } \\
\hline Speed of Convergence $(\lambda)$ & \multicolumn{2}{|c|}{$0,65 \%$} & \multicolumn{2}{|c|}{$0,84 \%$} & \multicolumn{2}{|c|}{$0,65 \%$} \\
\hline The Half-Life of Convergence & \multicolumn{2}{|c|}{106 Years } & \multicolumn{2}{|c|}{82 Years } & \multicolumn{2}{|c|}{106 Years } \\
\hline The Whole Life of Convergence & \multicolumn{2}{|c|}{212 Years } & \multicolumn{2}{|c|}{164 Years } & \multicolumn{2}{|c|}{212 Years } \\
\hline note : significance level $* * * 1 \%$, * & & & & & & \\
\hline
\end{tabular}

Source: Author (2020)

To decide the best model, we used the Fixed Effect Model. The classical assumption test indicates that the model exceeds multicollinearity but does not pass heteroscedasticity and autocorrelation. Therefore, it is necessary to improve classic assumptions using the Robust Standard Error (Satria, 2018). Based on Table 3, the Human Capital Index variable at the beginning of the year of analysis has a significant negative effect on the growth of the Human Capital Index at $\alpha=1 \%$. This means that provinces in Indonesia are experiencing a convergence of human capital conditionally at a rate of $0,84 \%$ per year, whereas Government Expenditure influences the conditional convergence on education. The Half-Life of Convergence and The Whole Life of Convergence are 82 years and 164 years, respectively. The convergence speed has increased from $0,65 \%$ to $0,84 \%$, so that the time needed to close half of the initial gap is faster, at 82 years, while the time needed to close the entire gap is 164 years.

As seen in the estimation results, government spending on education was able to accelerate the convergence process, but not significantly. This means that the amount of government spending so far has not succeeded in affecting the quality of human resources. The results of this study are in line with a study conducted by Bappenas (2019) which shows that at $20 \%$ of the state budget, the education budget has not been optimal and has not been included in the quality expenditure category. In realizing quality education, an adequate budget is needed to provide adequate human resources, organizational systems, infrastructure, and a conducive educational environment. Law Number 20 of 2003 concerning the National Education System states that the education budget is a minimum of $20 \%$ of the state budget and $20 \%$ of the regional budget, excluding teacher salaries and official education costs. This law also states that the central government and regional governments have the right to direct, guide, assist and supervise the delivery of education in accordance with the prevailing laws and regulations. Law Number 23 of 2014 also stipulates that education is included in Compulsory Government Affairs. Early childhood education and basic education (Elementary School and Junior High School) are the authority of the district municipal government, and secondary education (Senior High School and Vocational High School) is the provincial government's authority

One aspect that can show the output of government spending in education is the quality of educational infrastructure because the progress of a country to catch up with other countries is also very dependent on two other factors, the quality of institutions and the availability of infrastructure (Ministry of Finance, 2018). The 2019 Education Statistics shows that the main school infrastructure, such as classrooms, is still far from good. Classrooms for Elementary School level that are in good condition are only 24,57\%, Junior High School 29,16\%, Senior High School 43,01\%, and Vocational High School 51,26\% (BPS, 2019b). One of the most important aspects of the teaching and learning process is the availability of comfortable and safe learning facilities. School facilities and infrastructure must comply with predetermined educational quality standards and support a more conducive learning process. Unfortunately, the conditions of current classrooms are mostly damaged, either light, moderate, or completely damaged. Although efforts to improve the quality of school facilities and infrastructure have been rehabilitated or renovated by the Ministry of Education and Culture, the Ministry of Religion, and several other ministries, the government's ability to provide conducive classrooms to the teaching and learning process is not yet optimal (BPS, 2019b). 
Providing adequate infrastructure for the education process requires adequate allocation of funds. The allocation of funds from the capital to the regions has been regulated through the provisions of the General Allocation Fund and Special Allocation Funds to the regions. Presidential Regulation Number 141 of 2018 concerning Technical Guidelines for Physical Special Allocation Funds explains that this fund can be used to help finance special regional physical activities in accordance with national priorities, which of course, include educational matters. These funds can be used for the rehabilitation and construction of classrooms, libraries, and laboratories to support a conducive learning situation to produce higher quality output.

In addition to the quality of infrastructure, other aspects can show the output of government spending on education. The quality of infrastructure in Indonesia is still far from good. However, it is feared that this situation will cause the government to focus only on physical expenditures, even though many other aspects must be considered, such as teacher quality, teacher welfare, curriculum design, equitable education, and the high cost of tertiary education. This study does not focus on all aspects. However, it only focuses on how government spending in education can create equity in human capital as human capital in this study is an index formed from the dimensions of school enrolment rates. The school enrolment rate in Indonesia has decreased with increasing levels of education. In other words, the higher the level of education, the lower the enrolment rate. This phenomenon does not only occur on a national scale but also in all provinces. Thus, all provinces can be said to have the same problems. The difference only lies in the depth of the problems each province face, which is measured by the amount of the Human Capital Index.



Figure 3.Gap of Provincial Human Capital Index in Indonesia by Dimensions, 2005 - 2019 Source: Author's calculation (2020)

The magnitude of the human capital inequality in Indonesia is shown in Figure 3. The inequality is quite large at the junior high school, senior and vocational high school, and university, while the inequality at the primary level is relatively small. The budget for education largely determines how this school enrollment rate can be increased. The priority for regional funding allocation depends on the local government and the regional people's representative assembly. Since the education sector is one of the basic service sectors, there is a need for a minimum standard of education that regions must achieve as a reference in planning the education sector. The most important question regarding the direction of education decentralization is how schools as implementers of the education process have the autonomy to determine various policies regarding the organization and teaching-learning process, teacher management, planning at the school level, and sources of school funding. Thus, government spending on education should ideally not only increase in quantity from year to year, but also in quality. 
Some empirical results have shown that simply providing more resources to schools is generally ineffective. Local governments should be able to optimize funds for education to increase access and expand learning opportunities at the junior high school, high school, and vocational high school and university levels. Future strategies should focus on providing the largest proportion of the budget to increase access to higher education, targeting provinces included in the low Human Capital Index category. Accelerating the convergence process of human capital requires both budget quantity and accuracy of budget targeting. Government spending on education must be able to provide tangible results on the quality of education by allocating a budget accessible for each level of education.

\section{Conclusion}

Provinces in Indonesia experience absolute convergence of human capital, where the inequality of human capital between provinces tends to decrease over time and leads to equity. Provinces in Indonesia also experience conditional convergence of human capital, where government spending on education can accelerate the convergence process, but not significantly. Increasing the quality of human capital and maintaining its equal distribution is determined by many factors, given the heterogeneous condition of Indonesian society. However, one of the most critical factors that can be measured and be intervened is the education budget. Increasing the quality of budget use must also be accompanied by an increase in the quantity of the budget, which has increased from year to year.

\section{References}

Acemoglu, D., \& Autor, D. (2005). Lectures in Labor Economics, Chapter 1. Lectures Notes Manuscript. MIT.

Altiner, Ali., \& Toktas, Y. (2017). Relationship Between Human Capital and Economic Growth: An Application to Developing Countries. Eurasian Journal of Economics and Finance, 5(3), 87-98.

Azzizah, Y. (2015). Socio-Economic Factors on Indonesia Education Disparity. International Education Studies, 8(12), 218-229.

Bappenas. (2019). Anggaran Belanja Pendidikan 20\% APBN Belum Berkualitas. Retrieved from Https://Nasional.Kontan.Co.Id/News/Bappenas-Anggaran-Belanja-Pendidikan-20-Apbn-BelumBerkualitas on May 7, 2020.

Barro, Robert J., \& Sala-i-Martin, X. (1991). Convergence Across States and Regions. Brookings Papers on Economic Growth, 1(1), 107-158.

Barro, R. J. (2001). Human Capital and Growth. The American Economic Review, 91(2), 12-17.

Becker, G. . a. (2002). Human capital. Paper given at the University of Montevideo Retreieved from Www.Um.Edu.Uy/Docs/Revistafcee/2002/Humancapital Becker.Pdf, July 10, 2.

Becker, G. . b. (2002). The Age of Human Capital. Palo Alto: Hoover Institution Press. 3-8.

Benhabib, J., \& Spiegel, M. . (1994). The Role Of Human Capital In Economic Development Evidence From Aggregate Cross-Country Data. Journal of Monetary Economics, 34(2), 143-173.

Bloom, D. E., Canning, D., \& Jamison, D. T. (2004). Health, Wealth and Welfare. Finance and Development, 41(1), 10-15.

BPS a. (2019). Produk Domestik Regional Bruto Provinsi-Provinsi Di Indonesia Menurut Pengeluaran 20152019. Jakarta: BPS.

BPS b. (2019). Potret Pendidikan Indonesia Statistik Pendidikan 2019. Jakarta: BPS.

BPS. (2020). Indeks Pembangunan Manusia (IPM) Tahun 2019. Berita Resmi Statistik No. 21/02/Th. XXIII, 17 Februari 2020.

Busemeyer, M. . (2008). The Impact Of Fiscal Decentralisation on Education and Other Types of Spending. Swiss Political Science Review, 14(3), 451-481.

Channa, A., \& Faguet, J. . (2016). Decentralization of health and education in developing countries: a quality-adjusted review of the empirical literature. The World Bank Research Observer, 31(2), 199241.

Colantonio, E., Marianacci, R., \& Mattoscio, N. (2010). On human capital and economic development: some results for Africa. Procedia-Social and Behavioral Sciences, 9(1), 266-272.

de la Fuente, A. (2011). Human Capital and Productivity: Barcelona Graduate School of Economics. Retrieved from Http://Ideas.Repec.Org/ p/Bge/Wpaper/530. Html on July 10, 2020.

Esteller, Alejandro., \& Solé, A. (2005). Does Decentralization Improve the Efficiency in the Allocation of Public Investment? Evidence from Spain. Institut d'Economia de Barcelona (IEB) Working Papers $2005 / 5$. 
Finance, M. of. (2018). Pentingnya Pendidikan Tinggi Bagi Indonesia. Retrieved from Https://Www.Kemenkeu.Go.Id/Publikasi/Berita/Pentingnya-Pendidikan-Tinggi-Bagi-Indonesia/ on July 7, 2020.

Gennaioli Nicola, La Porta, Rafael, Lopez-de-Silanes, Florencio, \& S. A. (2013). Human Capital and Regional Development. Quarterly Journal of Economics, 128(1), 105-164.

Gillies, D. (2017). Human Capital Theory in Education. Encyclopedia of Educational Philosophy and Theory, $1-5$.

Gujarati, Damodar N., \& Porter, D. C. (2015). Dasar-Dasar Ekonometrika Edisi ke-5. Salemba Empat.

Hanushek, E. . (2013). Economic growth in developing countries: The role of human capital. Economics of Education Review, 37(1), 204-212.

Islam, R., Ghani, A.B.A., Kusuma, B., \& Theseira, B. . (2016). Education and Human Capital Effect on Malaysian Economic. International Journal of Economics and Financial Issues, 6(4).

Jalil, A. (1999). Pendidikan Setelah Era Orde Baru, Cakrawala Pendidikan. Jakarta: Universitas Terbuka.

Lucas, E., \& Shobayo, P. (2017). Effect of Expenditures on Education, Human Capital Development and Economic Growth in Nigeria. Nile Journal of Business and Economics, 3(5), 40-50.

Mankiw, Nicholas G., David Romer., \& D. N. W. (1992). A Contribution to the Empirics of Economic Growth. Quarterly Journal of Economics, 108(10), 407-437.

Mincer, J. (1995). Economic Development, Growth of Human Capital, and the Dynamics of the Wage Structure. Journal of Economic Growth, 48(744), 29-48.

Ministry of Education. (2019). Pentingnya Pendidikan Tinggi Bagi Indonesia. Retrieved from Http://Publikasi.Data.Kemdikbud.Go.Id/UploadDir/Isi_27CAE5B1-72E1-4854-A68236031334DA82_.Pdf on July 6, 2020.

Murthy, N.R Vasudeva, \& I. . C. (1997). The Empirics of Economic Growth for OECD Countries: Some New Findings. Economic Letters, 55, 425-429.

Musanna, A. \& Bahri, S. (2011). Quo Vadis Desentralisasi Pendidikan Di Indonesia Tinjauan Historis, Orientasi dan Reformulasi Desentralisasi Pendidikan. Jurnal IImiah Islam Futura, 10(2), 101-116.

Nurarifin, Ridena, S. (2020). The Role of ICT and Human Capital Development in Pursuing a Demographic Dividend and Improving Economic Welfare in Indonesia. The Journal of Indonesia Sustainable Development Planning, 1(2), 1(2), 113-124.

Oates, W. E. (1993). Fiscal Decentralization and Economic Development. National Tax Journal, 46(2), 237243.

Oates, W. E. (2005). Toward A Second-Generation Theory of Fiscal Federalism. International Tax and Public Finance, 12, 349-373.

Ocheni, S.I. \& Agba, M. . (2018). Fiscal Decentralisation, Public Expenditure Management and Human Capital Development in Nigeria. Academic Journal of Interdisciplinary Studies, 7(1), 153-165.

Purnastuti, L. \& Suprayitno, B. (2016). Does Human Capital Investment Matter For Growth? Evidence From Indonesia During The Fiscal Decentralization Era. Regional Science Inquiry, 8(1), 39-49.

Purwanto, E.A. \& Pramusinto, A. (2018). Decentralization and Functional Assignment in Indonesia: The Case of Health and Education Services. Policy Studies, 39(6), 589-606.

Sala-i-Martin, X. (1996). The Classical Approach to Convergence Analysis. The Economic Journal, 10191036.

Saraswati, E. (2012). Public Spending Education and Inequality: A case study in Indonesia. International Journal of Social Science and Humanity, 2(5), 427.

Satria, D. (2018). Analisis Regresi: Model Data Panel. Retrieved from Http://Www.Diassatria.Com/WpContent/Uploads/2018/05/Modul-PanelData-Eviews.Pdf on July 22, 2020.

Subijanto, S. (2010). Prinsip-Prinsip dan Efektivitas Desentralisasi Pendidikan Dalam Rangka Meningkatkan Mutu dan Relevansi Pendidikan. Jurnal Pendidikan Dan Kebudayaan, 16(5), 532-549.

Todaro, M.P., \& Smith, S. . (2011). Pembangunan Ekonomi Edisi ke-11. Jakarta: Erlangga.

UNDP. (2016). Human Development Report. Retrieved from Http://Hdr.Undp.Org/En/Content/HumanDevelopment-Index-Hdi on July 10, 2020.

Wahyudin, Dinn. \& Caturwati, E. (2019). Memaknai Angka Partisipasi Kasar Pendidikan Tinggi. Retrieved from Https://Komunita.Widyatama.Ac.Id/Memaknai-Angka-Partisipasi-Kasar-Pendidikan-Tinggi/ on July 10, 2020.

Work, R. (2002). Overview of Decentralization Worldwide: A Stepping Stone to Improved Governance and Human Development. Presented in International Conference on Decentralization with the Theme Federalism: The Future of Decentralising States 25-27 July, 2002, Manila, Philippines, UNDP (Pp. 120). 
World Economic Forum. (2017). The Global Human Capital Report 2017 World Economic Forum. Retrieved from Https://Www.Weforum.Org/Reports/the-Global-Human-Capital-Report-2017 on July 12, 2020.

Zhang, X., Li, H., Wang, X. \& Fleisher, B. . (2019). Human Capital and the Economic Convergence Mechanism: Evidence from China. Retrieved from Https://Www.lza.Org/Publications/Dp/12224/Human-Capital-and-the-Economic-ConvergenceMechanism-Evidence-from-China on July 12, 2020. 